\title{
COMUNICAÇÕES
}

\section{Natural occurrence of Colletotrichum coccodes (Wallr.) Hughes causing anthracnose on pepper (Capsicum annuum L.) in Brazil}

\author{
Hugo José Tozze Júnior ${ }^{1}$; Ricardo Gioria²; Olga Suzuki²; Kátia Regiane Brunelli²; \\ Renato Souza Braga ${ }^{2}$; Nelson Sidnei Massola Júnior ${ }^{1}$
}

\begin{abstract}
${ }^{1}$ ESALQ/USP, Setor de Fitopatologia, C.P. 09, 13418-900, Piracicaba, SP. ${ }^{2}$ SAKATA SEED SUDAMERICA, C.P. 427,12906-840, Bragança Paulista, SP.nmassola@esalq.usp.br

Data de chegada: 05/04/2006. Aceito para publicação em: 30/10/2006.
\end{abstract}

Anthracnose caused by Colletotrichum is one of the most important diseases of pepper (Capsicum annum). It causes severe damages to both field and post harvest levels in warm and rainy seasons. C. gloeosporioides, C. acutatum, C. capsici, and C. coccodes are the main species reported on this host worldwide. In Brazil, C. gloeosporioides is reported as agent of pepper anthracnose (Kurozawa et al., In: Kimati et al., Manual de fitopatologia, v.2, 4 ed., p.589-596, 2005.). Otherwise, Costa et al. (Fitopatologia Brasileira, v.30, suppl., p.140, 2005) demonstrated that $C$. coccodes from tomato can infect pepper through artificial inoculations.

On April 2005, diseased fruits of pepper were found in Caxias do Sul county, Rio Grande do Sul state. These fruits exhibited anthracnose lesions covered with salmon mass of conidia and many microsclerotia, which are typical signs of $C$. coccodes, already reported in Brazil on tomato (Lopes \& Avila, Doenças do tomateiro, 2005, 151p.) and potato (Mendes et al., Fungos em plantas no Brasil, 1998, 569p.).

The pathogen was isolated through collecting conidia directly from the lesions and plating them on PDA medium. Ripe fruits were inoculated by a small drop $(20 \mu \mathrm{L})$ of $10^{5}$ conidia $/ \mathrm{mL}$ suspension. After depositing the drop, the fruit epidermis was wounded by a sterile needle. Inoculated fruits were kept under wet chamber at $25+1{ }^{\circ} \mathrm{C}$ and 12 hours photoperiod. Three days after inoculation it were observed depressed lesions on the inoculated area. On the fifth day it was noticed intense sporulation of the pathogen. Microsclerotia (Fig. 1A and 1B) were found on the tenth day after inoculation. The pathogen was reisolated and submitted to cultural and morphological characterization, as well as to molecular (Polymerase Chain Reaction - PCR) identification.

Morphological characterization was performed by analyzing shape and sizes of 30 conidia, produced on inoculated fruits, using methodology described by Tozze Jr. et al. (Summa Phytopathologica, v.32, n.1., p.71-79, 2006). For the cultural characterization, the pathogen was cultured on PDA at $25^{\circ} \mathrm{C}$ and 12 hours photoperiod for 7 days. Molecular identification was achieved by PCR using $C$. coccodes specific primers Cc1NF1 and Cc2NR1 described by Cullen et al. (Plant Pathology, n.51, p.281-292, 2002). In all tests it were used typical isolates of C. coccodes (from potato), C. gloeosporioides (from papaya) and C. acutatum (from peach) as references.

The isolate obtained from pepper showed straight, fusiform, sometimes slightly constricted in the middle and abruptly tapered to each end conidia, measuring $20.0(14.6-22.6) \times 3.4(2.7-5.3) \mu \mathrm{m}$ (fig. 1C). These observations matched $C$. coccodes described by Sutton (In: Baley \& Jeger, Colletotrichum: biology, pathology and control, p.1-26, 1992). The cultural characterization revealed aerial mycelium white, sparse, with profuse production of microsclerotia (fig. 1D), similar to C. coccodes isolate used as reference. Finally, the PCR amplified a $349 \mathrm{bp}$ fragment from pepper and C. coccodes (potato) isolates (Fig 1E). This is the first report of $C$. coccodes as causal agent of pepper anthracnose in field conditions in Brazil.

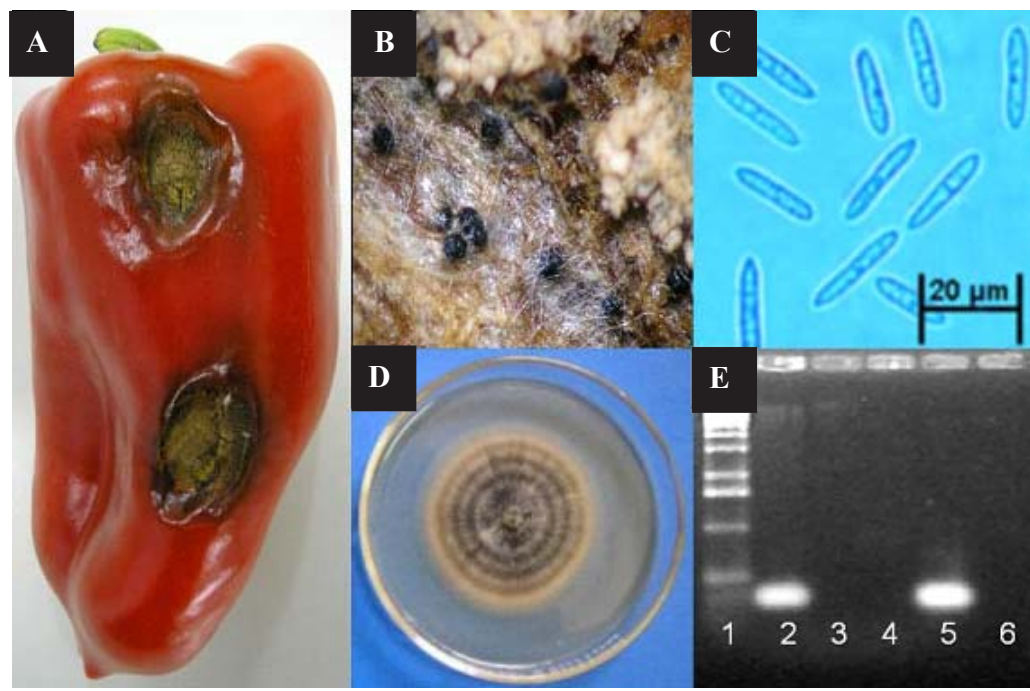

Figure 1. Aspects of C. coccodes isolated from pepper: (A) Symptoms on ten-days old inoculated fruit, (B) Microesclerotia on the lesions, (C) Conidia morphology, (D) Seven-days old colony on PDA; (E) PCR product in electrophoresis gel: 1- Ladder (1kb), 2-Colletotrichun coccodes (potato), 3-Colletotrichun acutatum (peach), 4Colletotrichun gloeosporioides (papaya), 5- Pepper isolate, 6- mix. Fragment observed: 349bp. 